\title{
TINJAUAN FILSAFAT HUMANISME: STUDI PEMIKIRAN PAULO FREIRE DALAM PENDIDIKAN
}

\author{
Rizky Very Fadli \\ Jurusan Sejarah Fakultas Ilmu Sosial \\ Universitas Negeri Malang \\ Email: rizkyfe13@gmail.com
}

\begin{abstract}
Abstrak
Pendidikan humanis adalah suatu proses pendidikan yang menganut alirat filsafat humanisme, dimana proses pendidikan menempatkan manusia sebagai salah satu objek terpenting dalam pendidikan. Pendidikan humanis didasari dengan persamaan kedudukan manusia, Paulo freire merupakan tokoh yang menggagas pendidikan humanis yang terkenal dengan konsep pendidikan dalam filsafat pendidikan humanisme, yaitu pendidikan yang membebaskan. Paulo Freire berperan dalam dinamika perkembangan pendidikan di Brazil. Latar belakang pemikirannya terbentuk atas realita ketimpangan pendidikan yang ada di daerahnya. Artikel ini berisikan tentang konsep pendidikan Paulo Freire yang beraliran filsafat humanisme. Tujuan dari penulisan artikel ini adalah mendeskripsikan pendidikan aliran filsafat humanisme dalam pemikiran Paulo Freire. Adapun jenis penelitian yang digunakan dalam penelitian ini adalah library research atau penelitian kepustakaan yang khusus mengkaji suatu masalah untuk memperoleh data dalam pembahasan.
\end{abstract}

Kata Kunci: Humanisme, Paulo Freire, Pendidikan

\section{PENDAHULUAN}

Filsafat merupakan tolak ukur manusia berdasarkan kemampuan menalar yang terjadi sebelum dan sesudahnya. Filsafat sangat berperan penting dalam dunia pendidikan yaitu dengan adanya sebuah kerangka acuan dalam filsafat pendidikan guna mewujudkan cita-cita pendidikan yang diharapkan. Filsafat pendidikan merupakan pemikiran secara mendalam sampai pada akarnya mengenai segala hal tentang pendidikan. Filsafat pendidikan dijabarkan dari filsafat (Djamaluddin, 2017). Filsafat pendidikan juga merupakan studi tentang semua permasalahan yang ada dalam pendidikan. Pendidikan merupakan upaya pengembangan potensi dalam diri seseorang melalui proses kegiatan belajar mengajar di lingkungan pendidikan. Artinya dalam hal ini filsafat pendidikan tidak boleh bertentangan dengan filsafat. Sesuai dengan tujuan pendidikan yang menciptakan pribadi yang seimbang, harmonis, dan dinamis dalam mencapai tujuan hidup. Melalui filsafat pendidikan, seorang pendidik dapat mengetahui hakikat pendidikan.

Mengkaji tentang persoalan pendidikan memang selalu menarik dalam dinamikannya. Terlebih mengenai konsep pendidikan yang menyinggung tentang moral 
dan realitas sosial kemanusiaan. Tokoh pemikir pendidikan yang terkenal dengan masalah-masalah sosial kemanusiaan adalah konsep pendidikan Paulo Freire. Perjuangan Paulo Freire tentang pemikirannya dalam hal pendidikan bagi kaum tertindas sangat populer dalam dunia internasional. Pendidikan yang membebaskan yang digagas olehnya begitu fenomenal. Pendidikan yang beraliran humanisme yang digagasnya dilatar belakangi oleh situasi ketimpangan pendidikan yang ada di wilayahnya sehingga memicu semangatnya untuk membangkitkan upaya penyadaran terhadap masyarakat agat dapat melihat sumber penyembab terjadinya ketimpangan tersebut. Penulisan artikel ini akan berfokus pada bagaimana aliran humanisme yang digagas oleh pemikir Paulo Freire.

\section{METODE PENELITIAN}

Artikel ini disusun menggunakan metode penelitian kualitatif yaitu library research. Menurut Sari \& Asmendri (2020) bahwa metode library research adalah suatu teknik pengumpulan data dengan melakukan pencarian dan membaca berbagai buku, literatur, catatan, serta berbagai laporan yang berkaitan dengan permasalahan yang diinginkan penulis. Penulis juga mengambil sumber-sumber

dari berbagai buku literatur serta jurnal-jurnal ilmiah online yang memiliki kaitan dengan materi yang penulis bahas.

\section{TEMUAN}

Dalam kajian ini ditemukan beberapa temuan yang diperoleh mengenai Aliran Filsafat Fenomenologi dalam Perspektik Paulo Freire tentang Pendidikan dari sumber literatur berupa buku maupun jurnal-artikel online. Paulo Freire sendiri merupakan tokoh pendidikan, teolog, dan humanis yang berasal dari Kota Refice, Brazil bagian timur. Dalam pergerakan di bidang pendidikan, Freire sangat berpengaruh dalam pemikirannya yang luar biasa terkenal dan fenomenal dikalangan internasional. Pemikirannya selalu berisikan tentang gugatan, protes, dan berontak terhadap segala hal penyelewengan pendidikan, terutama kesadaran manusia atas pendidikan. Freire juga merupakan kaum intelektual yang produktif dan berpikiran kritis tentang pendidikan (Rahma, 2017:2-3). Gagasan dan pemikirannya dibangun dengan kokoh karena didasarkan kemampuannya dalam melihat realitas yang terjadi di masyarakat. Menurut Manggeng (2005:41) pemikirannya dalam pendidikan dilatar belakangi oleh keadaannya di Brazil. Freire mengkritik sistem pendidikan yang dijalankan oleh pemerintah Brazil, karena menurutnya sistem pendidikan yang berjalan sama sekali tidak berpihak pada masyarakat miskin, namun justru hanya mengasingkan dan menjadi alat penindasan oleh penguasa. Karena alasan tersebut, maka sistem pendidikan yang demikian harus dihapuskan dan digantikan dengan sistem pendidikan yang baru.

Pergerakannya dalam dunia pendidikan didasarkan pada "pendidikan untuk orang tertindas", yakni pendidikan untuk keseluruhan bukan individu yang memiliki kuasa. Dalam perjuangannya, Freire tanpa henti untuk memperjuangkan kembali kemanusiaan mereka. pendidikan ini membuat penindasan dan penyebabnya 
menjadi obyek refleksi kaum tertindas, dan dari refleksi itulah lahir pembebasan (Freire, 2007). Tokoh Paulo Freire merupakan pemikir yang berpengaruh dalam teori dan praktik pendidikan kritis abad ke-20. Fokusnya pada peran pendidikan dalam memperjuangkan kaum tertindas diimplementasikan ke dalam konsep-konsep yang praktis untuk dijalankan dalam rangka menuntaskan kebodohan pendidikan di Brazil (Syaikhudin, 2012).

Pandangan Paulo Freire tentang pendidikan tertuang pada kritikannya yang tajam terhadap sistem pendidikan dan dalam pendidikan alternatif yang ia tawarkan. Kritikan maupun tawarannya pada pendidikan lahir dari suatu konteks nyata atau realitas yang Freire temukan sekaligus merujuk pada refleksi aliran filsafat pendidikannya tentang pemahaman manusia atau humanisme (Manggeng, 2005:41). Kondisi di Brazil saat itu merupakan pergolakan politik yang riskan dimana struktur masyarakat terbagi menjadi dua strata bagian yaitu strata masyarakat atas dan strata masyarakat bawah. Golongan atas menjadi penindas masyarakat bawah dengan memalui kekuasaan politik dan akumulasi kekayaan (Sumaryo dalam Manggeng, 2005:41). Kondisi tersebut akhirnya yang menyebabkan golongan masyarakat bawah menjadi semakin miskin yang sekaligus semakin menguatkan ketergantungan kaum tertindas kepada para penisdas itu. Dari penjelasan temuan tersebut, muncul aliran filsafat Paulo Freire yakni aliran Humanisme dimana berfokuskan pada pemahaman manusia.

\section{PEMBAHASAN}

Pendidikan Humanisme Paulo Freire

Pendidikan humanisme adalah proses pendidikan yang menganut aliran filsafat humanisme dimana proses pendidikan yang menempatkan manusia sebagai objek terpenting dalam pendidikan. Dalam hal yang lebih rinci, filsafat pendidikan humanisme menempatkan manusia sebagai objek pelaku yang sebenarnya dalam pendidikan itu sendiri. Aliran filsafat humanisme inilah yang dicita-citakan oleh Freire bahwa manusia adalah subjek atau pelaku utama dalam pendidikan (Djatman, 2005:109). Manusia memegang peranan penting dalam kehidupannya. Dalam hal ini, manusia merupakan pemegang kebebasan dalam melakukan sesuatu yang terbaik bagi dirinya sendiri. Sehingga kedudukannya sangatlah tinggi karena dibekali potensi-potensi kebebasan terutama dalam hal pendidikan. Manusia berhak mendapatkan pendidikan secara bebas demi mengembangkan kemampuan potensinya.

Pemikiran Freire mengenai humanisme yang dilatar belangkangi oleh situasi ketimpangan pendidikan di daerahnya menjadi pemicu semangatnya dalam membangkitkan upaya penyadaran masyarakat agar dapat melihat sumber

terjadinya ketimpangan tersebut. Pandangannya mengenai pendidikan humanisme dari latar belakang tersebut yakni terdapat struktur masyarakat yang sebagian menikmati kesenangan namun sebagian yang lain harus menderita dan meratapi 
penindasan. Secara spesifik, pemikiran humanisme Freire lebih mengarah pada "pembebasan", yakni bebas dari ketertindasan dan keterbelengguan dan segala hal tentang kebebasan manusia yang terganggu dari apapun (Freire, 2007). Dengan kata lain, banyak dari sebagian mereka yang menderita sementara sebagian lainnya menikmati jerih payah orang lain dengan cara yang tidak adil.

Beberapa konsep sentral dalam pemikiran Freire mengenai pendidikan yang membebaskan, yaitu : (Rahma, 2017:85).

\section{Penyadaran}

\section{Pendidikan hadap masalah}

\section{Alfabetisasi}

Humanisme dalam pengertian Freire bukanlah kebebasan individu. Tujuan dari humanisasi adalah tujuan sosial, dan kebutuhan manusia untuk menjadi makhluk bagi dirinya sendiri yang dikatakan terwujud ketika masyarakat mampu menjadi sesuatu untuk dirinya sendiri. Menurut Nata (2012) pendidikan Paulo Freire secara umum bercorak humanisme rekonstuksionis yakni, pendidikan yang diarahkan pada usaha membantu masyarakat terutama kaum tertindas dan pendidikan yang memberdayakan yang bertolak dari kepentingan masyarakat, bukan pada pendidikan yang didasari kepentingan penguasa.

Pembatasan pendidikan aliran humanismenya, Freire memberikan definisi yang memuat sebagian besar pemikirannya tentang konsep pendidikan humanis, menurutnya pendidikan humanis adalah (Yamin, 2005):

1.Pendidikan yang mempertegas dan memperjelas arah pendidikan dimana pendidikan harus membebaskan dan memerdekakan. Pengertian membebaskan dan memerdekakan adalah sebuah upaya pemberdayaan masyarakat tertindas menuju sebuah paradigma kritis dan transformatif dalam mewujudkan sebuah kebebasan sebagai hak asasi manusia yang mendapatkan pendidikan secara layak.

2.Pendidikan yang menjadi pengawal dan pendamping dalam segala hal dinamika kehidupan. Dalam kondisi ini Freire lebih menegaskan pada sebuah keadaan dalam kebudayaan, pengetahuan dan kondisi suatu kelompok masyarakat.

3.Pendidikan emansipatoris yaitu pendidikan yang bukan hanya menjalankan peranannya sebagai proses pengalihan pengetahuan, melainkan juga mengetahui dan harus menjadikan peserta didik sebagai makhluk yang menjadi subjek dan hidup secara aktif merasakan persoalan dan ikut terlibat dalam dinamika kehidupan.

Jadi pandangan pendidikan Freire merujuk pada manusia dimana masalah yang ada di dunia sebab adanya mausia dan realitas. Dalam hal ini, yang mejadi objek suatu masalah adalah kenyataan objektif antara manusia dengan kehidupan sosial, dimana manusia atau masyarakat yang melahirkan tindakan konflik, tindakan kreatif atau sebagainya merupakan sebuah kesinambungan dalam sebuah kehidupan sosial. 
Oleh karena itu, alternatif pendidikan "hadap masalah" yang ditawarkan Paulo Freire merupakan hal yang tepat. Yaitu suatu metodologi pendidikan yang menjadikan manusia sebagai subjek dalam pendidikan. Dengan pendidikan yang befokus pada menghadapi masalah yang terjadi di masyarakat, maka pendidikan hadap masalah ini akan semakin berkembang. Menurut Manggeng (2005:42) manusia tidak bisa terpisah dari dunia dan realitasnya, karena manusia pada dasarnya berada dalam dunia dan bersama dengan realitas dunia. Realitas ini yang harus dihadapkan pada peserta didik supaya ada rasa kesadaran terhadap realitas itu. Konsep pemikiran tersebut disandarkan pada pemahaman bahwa manusia mempunyai daya untuk berkreasi dan untuk membebaskan diri dari penindasan budaya, ekonomi, maupun politik.

Tujuan Pendidikan Paulo Freire

Paulo Freire beranggapan bahwa pendidikan yang ideal adalah pendidikan yang berorientasi pada pengenalan realitas diri manusia. Karena manusia adalah penguasa atas dirinya sendiri. Karena fitrah dari manusia adalah merdeka, dan

menjadi manusia yang bebas dari situasisituasi yang menindasnya. Dan inilah tujuan akhir dari filsafat humanisme dari Paulo Freire.

Freire mendasari landasan epistemologi dan aksionloginya dengan nilai kemanusiaan, Freire berpendapat bahwa kebebasan berpendapat dan berpikir adalah hak setiap manusia. Hak ini perlu adanya ruang sehingga terciptanya manusia yang tumbuh dengan imajinatif dan kreatif. Konsep tujuan pendidikan Paulo Freire sejalan dengan alasan itu, yakni tujuan pendidikan yang memberikan hak kekebasan dalam mengembangkan potensi dan kreativitasnya (Freire, 2007).

Berikut konsep tujuan pendidikan dalam pandangan Freire (Freire, 2007):

\section{Pendidikan untuk penyadaran}

Konsep penyadaran Freire yang paling utama adalah pendidikan untuk penyadaran manusia tentang realitas sosialnya. Freire memuliai program pendidikannya dengan mengkonseptualisasikan sebuah proses penyadaran yang mengarah pada konsep kebebasan yang disebut "Kemanusiaan yang lebih utuh". Setiap individu mampu melihat realita sosial secara kritis. Penyadaran dalam hal ini menjadi inti dari proses pendidikan. Dalam pendidikan harus mengandung muatan realistis, dalam materi ajar berhubungan dengan fenomena realitas sosial masyarakat. Sehingga tercipta peserta didik menjadi sadar akan kebutuhan, tantangan dan persoalan yang terkait dengan reaalitas sosial.

\section{Pendidikan untuk kebebasan}

Pendidikan merupakan nilai yang paling enting bagi proses pembebasan manusia. Pendidikan kebebasan berada dalam dua tahap. Yakni pertama, pendidikan menjadikan manusia sadar akan penindasan yang menimpa mereka dan melalui gerakan praktis untuk mengubah keadaan. Kedua, pendidikan merupakan proses permanen aksi budaya pembebasan.

3.Pendidikan untuk humanisasi 
Manusia adalah penguasa atas dirinya sendiri dan karena fitrah manusia adalah menjadi manusia merdeka, oleh karena itu menurut Freire humanisasi merupakan tujuan akhir dari pendidikan. Namun pemikirannya seringkali digagalkan oleh kaum penindas dan justru karena adanya

pengingkaran tersebut, humanisasi menjadi disadari. Pengingkaran biasanya berupa perlakuan tidak adil, pemerasan, dan kekejaman. Dari berbagai pengingkaran tersebut akhirnya menimbulkan perjuangan untuk menarik kembali harkat manusia yang hilang. Melalui pendidikan, harkat manusia akan kembali dan sadar akan penindasan.

Konsep Pendidikan Pembebasan Paulo Freire

\section{Penyadaran}

Kebebasan merupakan hal yang sangat diagungkan oleh Freire. Manusia merdeka yang mampu menjadi subjek dan bukan hanya objek yang hanya menerima sebuah perlakuan dari pihak lain. Menjadi manusia sadar yang bertindak sesuai dengan realita dan mampu mengatasi masalah-masalah secara sadar. Pada hakikatnya manusia mampu mengatasi keadaan dirinya dan lingkungannya dengan berbekal pikiran dan dengan tindakan untuk mengubah situasi yang selaras dengan apa yang kehendaki. Maka, dalam konteks ini kesadaran adalah esensi yang lebih tinggi daripada eksistensi (Ramadhan:2011).

Freire mengungkapkan bahwa pendidikan berada sebagai jalan menuju peningkatan kualitas intelektual dan potensi sumber daya manusia, dimana antara keduanya memiliki hubungan daya kreasi dan potensi yang harus selalu diutamakan sehingga tercipta dialog antara pendidik dan siswa yang menjadi sebuah interaksi yang dialektis. Menurut Freire (2007) bahwa dengan berpikir aktif dan berpikir sebagai pelaku, maka pendidikan humanis akan menumbuhkan kesadaran yang menjauhkan seseorang dari rasa takut. Dengan begitu, langkah awal penyadaran sangat menentukan bagi pendidikan menurut Freire dengan istilah Conscientienzaco. Yang dimaksud dengan Conscientienzaco adalah sebagai sebuah proses untuk menjadi manusia yang seutuhnya.

\section{Pendidikan hadap masalah}

Jika dilihat dari konsep pendidikan gaya bank, pengetahuan merupakan sebuah anugerah yang diberikan oleh mereka yang menganggap dirinya berpengetahuan kepada mereka yang dianggap tidak memiliki pengetahuan. Mengaggap bodoh kepada orang lain secara mutlak adalah sebuah ciri penindasan, dan berarti menyelewengkan arti pendidikan dan pengetahuan sebagai proses pencarian. Pendidikan gaya bank ini seperti pembelajaran di dalam kelas dengan sistem satu arah atau monolog. Dimana gaya pembelajaran hanya dari guru kepada siswa dan tidak interaktif.

Konsep pendidikan seperti itulah yang dikecam oleh Freire, karena konsep pendidikan seperti itu sangat tidak manusiawi. Maka pendidikan hadap masalah hadir demi suatu proses realitas secara terus menerus. Menurut Freire (2007) konsep pendidikan hadap-masalah menganggap bahwa dialog merupakan prasyarat dalam pendidikan dan menjadi penguak realitas 
yang terjadi. Sehingga dalam pelaksanaannya aka tercipta guru dan peserta didik yang kritis karena adanya dialog. Jadi bisa dikatakan, pendidikan hadap-masalah adalah kebalikan dari konsep pendidikan gaya bank yang lebih kepada gaya belajar satu arah atau monolog.

Pendidikan dialogis adalah pendidikan hadap-masalah yang merupakan alternatif untuk pendidikan gaya bank yang monolog. Muatan pendidikan harus disesuaikan dengan realitas di lapangan, karena Freire beranggapan bahwa segala sesuatu yang ada di dunia ini adalah hukum sebab-akibat dan bukan terjadi begitu saja. Tema yang ditawarkan dalam pendidikannya adalah ketimpangan, kelaparan, keterbelakngan, ketergantungan, budaya bisu atau taktik pendidikan anti diaologis yang harus diselesaikan sesuai dengan realitas (Collins:2011). Konsep pendidikan hadapmasalah meganggap bahwa pendidikan dialogis berlaku sebagai penguak realitas. Sehingga melalui pendidikan yang dialogis akan mendorong guru dan peserta didik menjadi pemikir yang kritis.

\section{KESIMPULAN}

Paulo Freire merupakan tokoh pendidikan, teolog, dan humanis yang berasal dari Kota Refice, Brazil bagian timur. Paulo Freire sangat berpengaruh dalam pemikirannya yang luar biasa terkenal dan fenomenal dikalangan internasional. Pemikirannya selalu berisikan tentang gugatan, protes, dan berontak terhadap segala hal penyelewengan pendidikan, terutama kesadaran manusia atas pendidikan. Freire juga merupakan kaum intelektual yang produktif dan berpikiran kritis tentang pendidikan. Pendidikan humanisme adalah proses pendidikan yang menganut aliran filsafat humanisme dimana proses pendidikan yang menempatkan manusia sebagai objek terpenting dalam pendidikan. Dalam hal yang lebih rinci, filsafat pendidikan humanisme menempatkan manusia sebagai objek pelaku yang sebenarnya dalam pendidikan itu sendiri. Aliran filsafat humanisme inilah yang dicitacitakan oleh Freire bahwa manusia adalah subjek atau pelaku utama dalam pendidikan.

Paulo Freire beranggapan bahwa pendidikan yang ideal adalah pendidikan yang berorientasi pada pengenalan realitas diri manusia. Karena manusia adalah penguasa atas dirinya sendiri. Karena fitrah dari manusia adalah merdeka, dan menjadi manusia yang bebas dari situasi-situasi yang menindasnya. Dan inilah tujuan akhir dari filsafat humanisme dari Paulo Freire. Tujuan pendidikan menurut Freire sendiri meliputi pendidikan untuk penyadaran, pendidikan kebebasan, dan pendidikan untuk humanisasi. Dimana kesemuanya merupakan tujuan pendidikan yang beraliran filsafat humanisme yang memandang manusia merupakan objek utama dari pendidikan dengan memandang realitas sosial masyarakat.

\section{Daftar Pustaka}

Alfiyah, H. Y. (2013). Konsep Pendidikan Imam Zarnuji dan Paulo Freire. Jurnal Pendidikan Agama Islam (Journal of Islamic Education Studies), 1(2), 201221. 

p-ISSN: 2503-1228; e-ISSN: 2621-4172

Collins, D. (2011). Paulo Freire: Kehidupan, Karya \& Pemikirannya. Terjemahan Heyneardhi.

Djamaluddin, A. (2014). Filsafat Pendidikan. Istiqra: Jurnal Pendidikan dan Pemikiran Islam, 1(2).

Djatman, D. (2005). Psikologi Terbuka. Semarang:Limpad

Freire, P. (2007). Politik pendidikan: Kebudayaan, kekuasaan, dan pembebasan. Yogyakarta: Pustaka Pelajar.

Manggeng, M. (2005). Pendidikan Yang Membebaskan Menurut Paulo Freire dan Relevansinya dalam Konteks Indonesia. Artikel yang Dimuat dalam INTIM â€"Jurnal Teologi Kontekstual Edisi, (8).

Rahma, A. (2017). Pendidikan Humanis Paulo Freire Dalam Perspektif
Pendidikan Islam (Doctoral dissertation, IAIN Raden Intan Lampung).

Ramadhan, M. (2011). Teologi Kemanusiaan Studi atas Pemikiran Ali Syariati. Jurnal THEOLOGIA, 22(2).

Syaikhudin, A. (2012). Konsep pemikiran pendidikan menurut paulo freire dan ki hajar dewantoro. Cendekia: Jurnal Kependidikan Dan Kemasyarakatan, 10(1), 79-92.

Sari, M. \& Asmendri. (2020). Penelitian Kepustakaan (Library Reseacrh) dalam Penelitian Pendidikan IPA. Jurnal Pendidikan Bidang IPA dan Pendidikan IPA, Vol 6, No 1, dari ejournal.uinib.ac.id

Yamin, M. (2009). Menggugat Pendidikan Indonesia: Belajar dari Paulo Freire dan Ki Hadjar Dewantara. Ar-Ruzz Media 